\title{
Neotropical Monogenoidea. 40. Protorhinoxenus prochilodi gen. n., sp. n. (Monogenoidea: Ancyrocephalinae), parasite of Prochilodus lineatus (Characiformes: Prochilodontidae) from South Brazil
}

\author{
Marcus V. Domingues ${ }^{1}$ and Walter A. Boeger ${ }^{1,2}$ \\ ${ }^{1}$ Curso de Pós Graduação em Ciências Biológicas - Zoologia, Departamento de Zoologia, Universidade Federal do Paraná, \\ Curitiba, Caixa Postal 19073, PR 81.531-990, Brasil; \\ ${ }^{2}$ Research fellow of the Conselho Nacional de Desenvolvimento Científico e Tecnológico (CNPq)
}

Key words: Monogenoidea, Dactylogyridae, Ancyrocephalinae, Protorhinoxenus prochilodi, Characiformes, Prochilodus

\begin{abstract}
The monotypic Protorhinoxenus gen. n. is proposed to accommodate a species with the following characteristics: 1) tubular sclerotised vagina, 2) vaginal pore dextrolateral, 3) ventral and dorsal anchors with undifferentiated elongate shaft and base (representing approximately $2 / 3$ of the length of anchor), and 4) superficial and deep roots of ventral and dorsal anchors lacking. Protorhinoxenus prochilodi sp. $\mathrm{n}$. is described from the gills of Prochilodus lineatus (Valenciennes) of the Represa Capivari-Cachoeira, Municipality of Campina Grande do Sul, metropolitan area of Curitiba, Paraná. Specimens of other probable new species of Protorhinoxenus are reported from Prochilodus lineatus of the Rio Paranapanema, Municipality of Salto Grande, São Paulo; Hoplias spp. of the Rio Dois de Fevereiro, Municipality of Antonina, Paraná, and the Rio Piraquara, metropolitan area of Curitiba, Paraná; Leporinus elongatus Valenciennes of the Rio Tibagi, Municipality of Jataizinho, Paraná; and Schizodon fasciatum Agassiz of the Rio Solimões, island of Marchantaria, near Manaus, Amazonas. Protorhinoxenus appears to be a sister group of Rhinoxenus Kritsky, Boeger et Thatcher, 1988 based on the following apparent synapomorphies: 1) ventral and dorsal anchors lacking superficial and deep roots, 2) ventral and dorsal anchors with elongate shaft, and 3) male copulatory organ with counterclockwise rings.
\end{abstract}

During a study of gill parasites of characiform fishes of the Neotropical Region, specimens of a new species of Monogenoidea were collected from Prochilodus lineatus (Valenciennes) (Prochilodontidae). This species is described here as the only member of a newly proposed genus of Ancyrocephalinae. Species of other families of Characiformes are also reported as hosts of other apparent new species of the new genus.

\section{MATERIALS AND METHODS}

Hosts were collected with cast or gill nets from several locations in Brazil (as indicated below). Gill arches and the contents of the nasal cavities were placed in vials containing formalin $1: 4000$. After $1 \mathrm{~h}$, each vial was vigorously shaken and formalin was added to obtain a $5 \%$ solution. In the laboratory, the contents of each vial were examined under a dissecting microscope and the helminths were collected with the aid of probes. Some specimens were stained with Gomori's trichrome (Humason 1979) for study of internal morphology; others were mounted in Hoyer's medium (Humason 1979) for study of the sclerotised parts, as described by Kritsky et al. (1986). Measurements, in micrometres, were obtained with an ocular micrometer; the average is followed by the range and the number of measured structures (n) in parentheses. All measurements follow the procedure of Kritsky et al. (1986). Illustrations were prepared with the aid of a camera lucida attached to a phase-contrast microscope. Type specimens and vouchers are deposited in the parasite collections of Coleção
Helmintológica do Instituto Oswaldo Cruz (CHIOC), Rio de Janeiro, RJ, Brazil; Instituto Nacional de Pesquisas da Amazônia (INPA), Manaus, AM, Brazil; U.S. National Parasite Collection (USNPC), Beltsville, Maryland, USA; Institute of Parasitology, Academy of Sciences of the Czech Republic, České, Budějovice, Czech Republic (IPCR), as indicated in the description section.

\section{RESULTS}

POLYONCHOINEA Bychowsky, 1937

D a c ty logyrida e Bychowsky, 1933

A ncyrocephalina e Bychowsky, 1937

\section{Protorhinoxenus gen. n.}

Diagnosis. Body divided into cephalic region, trunk and haptor; peduncle inconspicuous. Tegument lacking scales or spines. Eyes 4. Pharynx muscular, glandular; intestinal caeca 2, confluent in posterior trunk, lacking diverticula. Gonads overlapping; testis dorsal to germarium. Common genital pore near bifurcation of caeca. Vas deferens apparently looping left caecum; seminal vesicle a dilation of vas deferens. Copulatory complex comprising sclerotised male copulatory organ and accessory piece; male copulatory organ a coiled tube with counterclockwise rings (Kritsky et al. 1985), base inflated; accessory piece articulated with base of male copulatory organ by copulatory ligament. Seminal receptacle anterior to germarium. Vagina sclerotised; vaginal aperture simple, 
dextrolateral; vaginal vestibule present, with nonsclerotised wall. Vitellaria follicular. Haptor with 14 hooks with ancyrocephaline distribution (Mizelle 1936), comprising shank of two subunits; ventral and dorsal bar; pair of ventral and dorsal anchors; anchors with shaft and base undifferentiated, lacking superficial, deep roots. Parasites of gills of Neotropical characiform fishes.

E t y molog y: The generic name is from the Greek (proto $=$ first, original $+r h i n / o=$ nose $+x e n / o=$ guest $)$ and refers to the proposed close phylogenetic relationship of the new genus to Rhinoxenus Kritsky, Boeger et Thatcher, 1988, a genus with species that parasitise the nasal cavities of characiform fishes, and the hypothesis that the gill filament is likely the site of parasitism of the ancestor for both genera (see below).

$\mathrm{T}$ y p e s p e c i e s : Protorhinoxenus prochilodi $\mathrm{sp}$. n. from Prochilodus lineatus (Valenciennes, 1836) (Characiformes: Prochilodontidae).

$\mathrm{O}$ t h e r s p e c i e s : Protorhinoxenus spp. from Prochilodus lineatus (CHIOC 34544A-34544B), Rio Paranapanema, Municipality of Salto Grande, São Paulo (April 1993); Hoplias spp. (CHIOC 34546-34547-34548; INPA 415; IPCR M-366), Rio Dois de Fevereiro, Municipality of Antonina, Paraná (July 1994) and Rio Piraquara, metropolitan area of Curitiba, Paraná (July 1992 and May 1998); Leporinus elongatus Valenciennes (CHIOC 34545), Rio Tibagi, Municipality of Jataizinho, Paraná (June 1997); Schizodon fasciatum Agassiz (USNPC 79264), Rio Solimões, Ilha da Marchantaria, near Manaus, Amazonas (September 1983).

\section{Protorhinoxenus prochilodi sp. n.}

Figs. 1-9

Description (based on 4 specimens): Body $459(\mathrm{n}=1)$ long; greatest width $100(\mathrm{n}=1)$ at midlength. Cephalic lobes poorly developed or absent; 3 pairs of head organs; unicellular, bilateral cephalic glands lateral, posterolateral to pharynx. Accessory eye granules oval, infrequently scattered in cephalic area. Pharynx oval, $23(\mathrm{n}=1)$ in diameter. Haptor trapezoidal, $112(\mathrm{n}=1)$ long, $186(\mathrm{n}=1)$ wide. Ventral anchor $171(145-186 ; n=3)$ long, base 44 $(40-49 ; n=3)$ wide; base with sclerotised cap projection for articulation with ventral bar; shaft+base long, straight; point short. Dorsal anchor $114(\mathrm{n}=2)$ long, base $8(8-9$; $n$ $=2$ ) wide, with shaft+base long, straight, point short. Ventral bar $73(61-85 ; n=2)$ long, flattened, with anterior margin bent backwards. Dorsal bar $37(\mathrm{n}=1)$, with small anterolateral projections. Hooks similar, with erect thumb, shaft and evenly curved point; proximal half of shank dilated. Hook pair 2, $26(24-28 ; n=3)$ long; hook pair 3, $62(60-63 ; \mathrm{n}=2)$ long; hook pairs 4,5 and 6,54 (47$57 ; \mathrm{n}=6$ ) long; hook pairs 1 and 7 , not measured. Male copulatory organ sclerotised, a coiled tube with approximately 5 rings, bulbous base; greatest ring diameter $24(22-28 ; n=3)$. Accessory piece with wide distal portion, serving as guide to male copulatory organ; copulatory ligament heavily coiled, passing within rings of male copulatory organ. Testis $35(n=1)$ long, $33(n=1)$ wide; seminal vesicle pyriform. Germarium $71(\mathrm{n}=1)$ long, $35(\mathrm{n}=1)$ wide. Ootype not observed. Vagina sclerotised, comprising proximal bulb and elongate coiled sclerotised tube. Seminal receptacle pyriform, $53(n=1)$ long. Vitellaria coextensive with caeca; vitelline commissure anterior to germarium. Eggs not observed.

$\mathrm{T}$ y $\mathrm{p}$ e $\mathrm{h}$ o s $\mathrm{t}$ : Prochilodus lineatus (Valenciennes, 1836) (Characiformes: Prochilodontidae).

S i te of infestation: Gill filaments.

T y p e 1 o c a li ty: Represa Capivari-Cachoeira, Municipality of Campina Grande do Sul, metropolitan area of Curitiba, Paraná (May and June 1995).

S p e c i m e n s s t u d i e d: holotype, CHIOC $34542 ; 1$ paratype, CHIOC 34543; 1 paratype, INPA 414; 1 paratype, IPCR M-366.

E t y molog y: The specific epithet refers to the genus of the fish host.

\section{DISCUSSION}

Protorhinoxenus prochilodi is a member of Ancyrocephalinae (sensu Kritsky and Boeger 1989) based on the anatomy of internal organs, and morphology and number of haptoral sclerites. The new genus is characterised by and distinguished from other genera of the subfamily by the combination of the following features: 1) a tubular sclerotised vagina, 2) vaginal pore dextrolateral, 3) ventral and dorsal anchors with elongate shaft and base (representing approximately $2 / 3$ of the length of the anchor), and 4) superficial and deep roots of ventral and dorsal anchors lacking.

Although Protorhinoxenus is being proposed as monotypic, specimens of additional candidate species of this genus have been collected from two species of anostomid, one erythrinid and one prochilodontid hosts from distinct areas in Brazil. However, the small number of specimens available for each parasite form hinders the recognition of their taxonomic status and description. Some, however, are expected to represent new species of Protorhinoxenus based on the evolutionary distance of their hosts. Comparative measurements of sclerotised structures of all these specimens are presented in Table 1.

Kritsky et al. (1988) report one undescribed species of Rhinoxenus Kritsky, Boeger et Thatcher, 1988 from the nasal cavities of Schizodon fasciatum (Anostomidae) (USNPC 79264). However, the study of these specimens indicates that they also represent an additional candidate species of Protorhinoxenus. Kritsky et al. (1988) suggest that the nasal cavities of the hosts are the specific site of infestation for this parasite. However, since no specimen has been collected from the nasal cavities in the present study, we propose that the site of infestation of these parasites are the gill filaments and that their finding in the nasal cavities is accidental. 


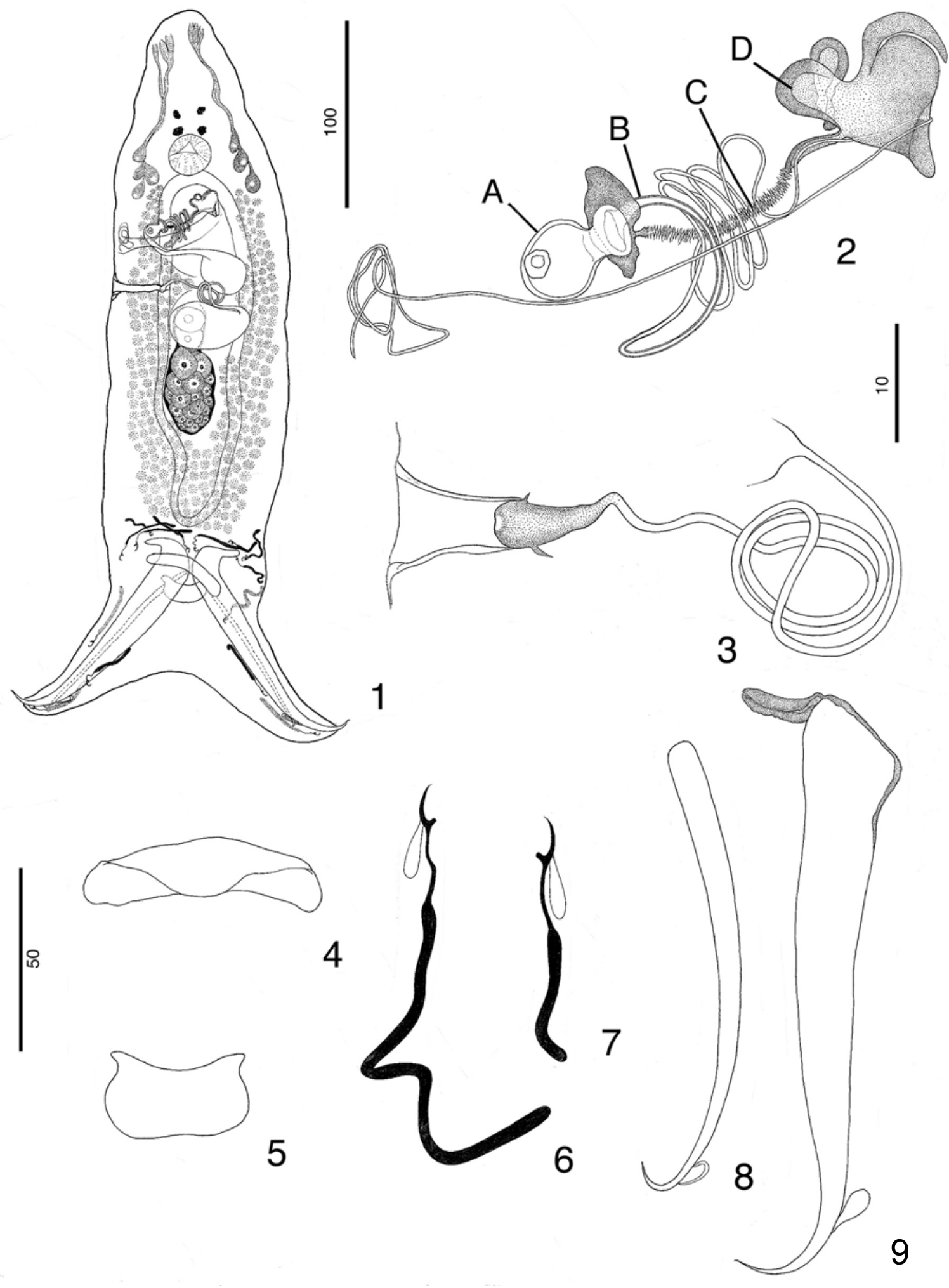

Figs. 1-9. Protorhinoxenus prochilodi sp. n. Fig. 1. Holotype (ventral). Fig. 2. Male copulatory organ. Fig. 3. Vagina. Fig. 4. Ventral bar. Fig. 5. Dorsal bar. Fig. 6. Hook pairs 1, 3-7. Fig. 7. Hook pair 2. Fig. 8. Dorsal anchor. Fig. 9. Ventral anchor. Scale bars: Fig. $1=100 \mu \mathrm{m}$; Figs. 2, 3, 6, $7=10 \mu \mathrm{m}$; Figs. 4, 5, 8, 9 =50 $\mu \mathrm{m}$. A - base of the male copulatory organ; B - male copulatory organ; $\mathrm{C}$ - copulatory filament; D - accessory piece. 
Table 1. Comparative measurements (in micrometres) of sclerotised structures of specimens of Protorhinoxenus spp. from four characiform hosts (collected at distinct localities; see Diagnosis of the genus).

\begin{tabular}{|c|c|c|c|c|c|c|c|c|}
\hline & $\begin{array}{l}\text { Prochilodus } \\
\text { lineatus }\end{array}$ & $\mathrm{n}$ & Hoplias spp. & $\mathrm{n}$ & $\begin{array}{l}\text { Leporinus } \\
\text { elongatus }\end{array}$ & $\mathrm{n}$ & $\begin{array}{c}\text { Schizodon } \\
\text { fasciatum ** }\end{array}$ & $\mathrm{n}$ \\
\hline Copulatory organ & & & & & & & & \\
\hline Ring diameter & 34 & 1 & $25(25-26)$ & 2 & 33 & 1 & 20 & 1 \\
\hline Ventral anchor & & & & & & & & \\
\hline Length & 125 & 1 & $181(169-190)$ & 3 & 181 & 1 & 220 & 1 \\
\hline Base width & 47 & 1 & $64(58-73)$ & 3 & 54 & 1 & 62 & 1 \\
\hline Dorsal anchor & & & & & & & & \\
\hline Length & 108 & 1 & $165(155-176)$ & 2 & 167 & 1 & - & - \\
\hline Base width & 10 & 1 & $11(11-12)$ & 3 & 11 & 1 & 8 & 1 \\
\hline Bar length & & & & & & & & \\
\hline Ventral & 80 & 1 & $121(115-130)$ & 3 & 91 & 1 & - & - \\
\hline Dorsal & - & - & $47(38-55)$ & 2 & - & - & - & - \\
\hline Hook length & & & & & & & & \\
\hline Pair 1 & - & - & - & - & - & - & - & - \\
\hline Pair 2 & - & - & 44 & 1 & - & - & - & - \\
\hline Pair 3 & 60 & 1 & 45 & 2 & 45 & 1 & - & - \\
\hline Pair 4 & 59 & 1 & - & - & - & - & - & - \\
\hline Pair 5 & 56 & 1 & $42(40-43)$ & 2 & 40 & 1 & - & - \\
\hline Pair 6 & - & - & - & - & - & - & - & - \\
\hline Pair 7 & - & - & - & - & - & - & - & - \\
\hline
\end{tabular}

* Locality: Rio Paranapanema, Municipality of Salto Grande, São Paulo.

**Protorhinoxenus sp. from $S$. fasciatum was reported as Rhinoxenus sp. by Kritsky et al. (1988).

Rhinoxenus and Protorhinoxenus are apparently sister genera, as suggested by the following synapomorphies: 1) ventral and dorsal anchors with superficial and deep roots lacking, 2) elongate shaft, and 3) male copulatory organ with counterclockwise rings. No other ancyrocephaline presents these characteristics concomitantly, supporting the proposed sister-group relationship. However, species of the new genus can be easily differentiated from Rhinoxenus spp. by having 1) dorsal bar (absent in Rhinoxenus spp.) and 2) vaginal aperture dextrolateral (sinistral in Rhinoxenus spp.).
Acknowledgements. The authors wish to thank the following individuals and agencies for supporting this study: Flávio Popazoglo, Euclides C. Grando Jr., Almir P. Barreto, Gislaine Otto, Kerlen Engers and Geraldo S. Simião helped during collection of hosts; Dr. Carlos A.S. de Lucena (Museu de Ciência e Tecnologia, Pontifícia Universidade Católica-RS) identified the fish hosts; Ralph Lichtenfels and Patricia Pillit, USNPC allowed access to specimens under their care; Dr. Delane C. Kritsky (Idaho State University, USA) provided a presubmission review of the manuscript. This study was partially supported by the Conselho Nacional de Desenvolvimento Científico e Tecnológico (CNPq) and Fundação Coordenação de Aperfeiçoamento de Pessoal de Nível Superior (CAPES).

\section{REFERENCES}

HUMASON G.L. 1979: Animal Tissue Techniques. W.H. Freeman Co., USA, 661 pp.

KRITSKY D.C., BOEGER W.A. 1989: The phylogenetic status of the Ancyrocephalidae Bychowsky, 1937 (Monogenea: Dactylogyridae). J. Parasitol. 75: 207-211.

KRITSKY D.C., BOEGER W.A., THATCHER V.E. 1985: Neotropical Monogenea. 7. Parasites of the pirarucu, Arapaima gigas (Cuvier), with description of two new species and redescription of Dawestrema cycloancistrum Price and Nowlin, 1967 (Dactylogyridae: Ancyrocephalinae). Proc. Biol. Soc. Wash. 98: 321-331.
KRITSKY D.C., BOEGER W.A., THATCHER V.E. 1988: Neotropical Monogenea. 11. Rhinoxenus, new genus (Dactylogyridae: Ancyrocephalinae) with descriptions of three new species from the nasal cavities of Amazonian Characoidea. Proc. Biol. Soc. Wash. 101: 87-94.

KRITSKY D.C., THATCHER V.E., BOEGER W.A. 1986: Neotropical Monogenea. 8. Revision of Urocleidoides (Dactylogyridae, Ancyrocephalinae). Proc. Helminthol. Soc. Wash. 53: 1-37.

MIZELLE J.D. 1936: New species of trematodes from gills of Illinois fishes. Am. Midl. Nat. 17: 785-806. 